\title{
INFLUENCE OF THE WATER LEVEL OF A TIDAL RIVER AND PRECIPITATION ON THE AMOUNT OF DISCHARGE FROM FLOWING WELLS*
}

\author{
A CASE STUDY OF THE LEFT BANK SIDE OF LOWER REACH \\ OF TONE THE RIVER, IBARAKI PREFECTURE-
}

\section{Hiroki TAKAMURA**}

\begin{abstract}
目的 : 感潮河川の河岸地域に打ける自噴泉湧出量は, 河川水位, 降雨の影響を受けて変化する. 本研究は, これらの影響の機構を明らかにするため, 鹿島半島の利根川沿岸の自噴帯の中から目的にあうような自噴井 戸を選び観測した。．その結果，課題の究明に必要な若干の資料を得たので，その一部を報告してご意見を仰 ぎたい，方法：自噴泉湧出量の観測は，利根川河口から $15.5 \mathrm{~km}$ の位置にあるA泉（離岸距離 $92 \mathrm{~m}$ ), B 泉 (離岸距離 $300 \mathrm{~m})$ について行なった．結果 : 年平均湧出量 $(108.2 \mathrm{l} / \mathrm{min}$.$) よりも少ない部分 (105 \mathrm{l} / \mathrm{min}$. が卓越湧出量である.これを中心にして，1 年間が三つの時期に分かれた. 先ず, コンスタントに約 $105 l$ $\mathrm{min}$ 。を湧出している時期が平水期（11月 25 日〜 3 月 25 日），それより減水している時期が渴水期（8月 1 日〜 月 18 日と 7 月 16 日〜 8 月 15 日), それより増加している時期が豊水期（ 9 月 19 日〜11月 20 日と 3 月 26 日〜 7 月 15 日）となる．観測期間の総降雨高（1658.2 mm）に対する上記の各期の割合は，豊水期 $70 \%$ ，平水期 $17 \%$ ，渇水期 $13 \%$ となっている．降雨の少ない 12 月，1月よりも 8 月， 7 月の湧出量が少な い理由としては, 蒸発散, 灌溉用揚水による影響が現われているためと思われる. 渇水期の湧出量には, 河 川水位の感潮型変化が鮮明に現われた. 豊水期には, 涌出量が台風型降雨のため実質的に増加する. 湧出量 の月別最高 $h \max .$, 最低 $h \mathrm{~min}$. の年平均涌出量 $Q \bar{x}$ からの差, すなわち, 月偏差をそれぞれ $\Delta Q_{h}, \Delta Q_{l}$ とすれば，月変幅量 $\Delta Q$ は， $\left|\Delta Q_{h}+\Delta Q l\right|$ となる. $\Delta Q$ は, $6 \cdot 9 \cdot 10$ の多雨月に大きく, 1 月 4 月の少雨 月に小さいのは, 地下水の涵養量との関係によるものと思われる. また, $\mathrm{A}$ 泉, B泉の涌出量の経時変化は, 離岸距離に比例して減少する.
\end{abstract}

\section{Introduction}

It is known by studies of O.E. Meinzer ${ }^{1)}, \mathrm{K}$. Keilhack ${ }^{2)}$ and L. Nilsson ${ }^{3)}$ that the changes of the water levels of sea or river influence upon the levels of nearby ground water. In Japan the fact is also ascertained by Kinzô Seno(3), Zennosuke Andôn ${ }^{6)}$ and Ryûji Nomitsu ${ }^{7)}$ at Beppu Hot Springs. Almost the same result as the Seno's has been found in the data collected by the present writer in Nii-jima of the Izu Islands south of Tôkyô (unpublished).

* Read at the annual meetings in 1969 and 1970 of the Association of Japanese Geographers.

** Department of Geography, Risshô University.

1) Meinzer, O.E. mentions in the Ground Water in the United States-in Summary U. S. Geol. Surv., Water Supply Paper 836-D (1939) that the water level of the piestic ground well, 100 feet away from the coast of Mattawoman Creek (Maryland), is affected by the tide.

2) Keilhack, K. (1917) : Lehrbuch der Grundwasser und Qellenkunde, Berlin, 2 Aufl.

3) Nilsson, Lars Y. (1966) : Short-Time Variation of the Ground Water and Its Reason, Ground Water Problems, pp. 57-72.

4) Seno, Kinzô and others (1940): Beppu Hot Springs and the Tide, with special notes on Atmospheric Pressure Effect. Chikyû-butsuri (Journal of Geophysics), Vol.2, No. 1, pp. 1-23.

5) Seno, Kinzô (1940): The Distribution of the Tidal Efficiency in Beppu Hot Springs, Chikyû-butsuri (Journal of Geophysics), Vol.2, No. 1, pp. 24-31.

6) Andô, Zennosuke (1934): The Change of the Well Water Level with Ebb and Flow. Doboku-Kôgaku (Journal of Civil Engineering), Vol. 3, No.6, pp. 407-413.

7) Nomitsu, Ryûji (1949): A Study of the Coastal Ground Water (the third) —-2, Chikyû-butsuri (Journal of Geophysics), Vol.3, No.6, pp. 109-118. 


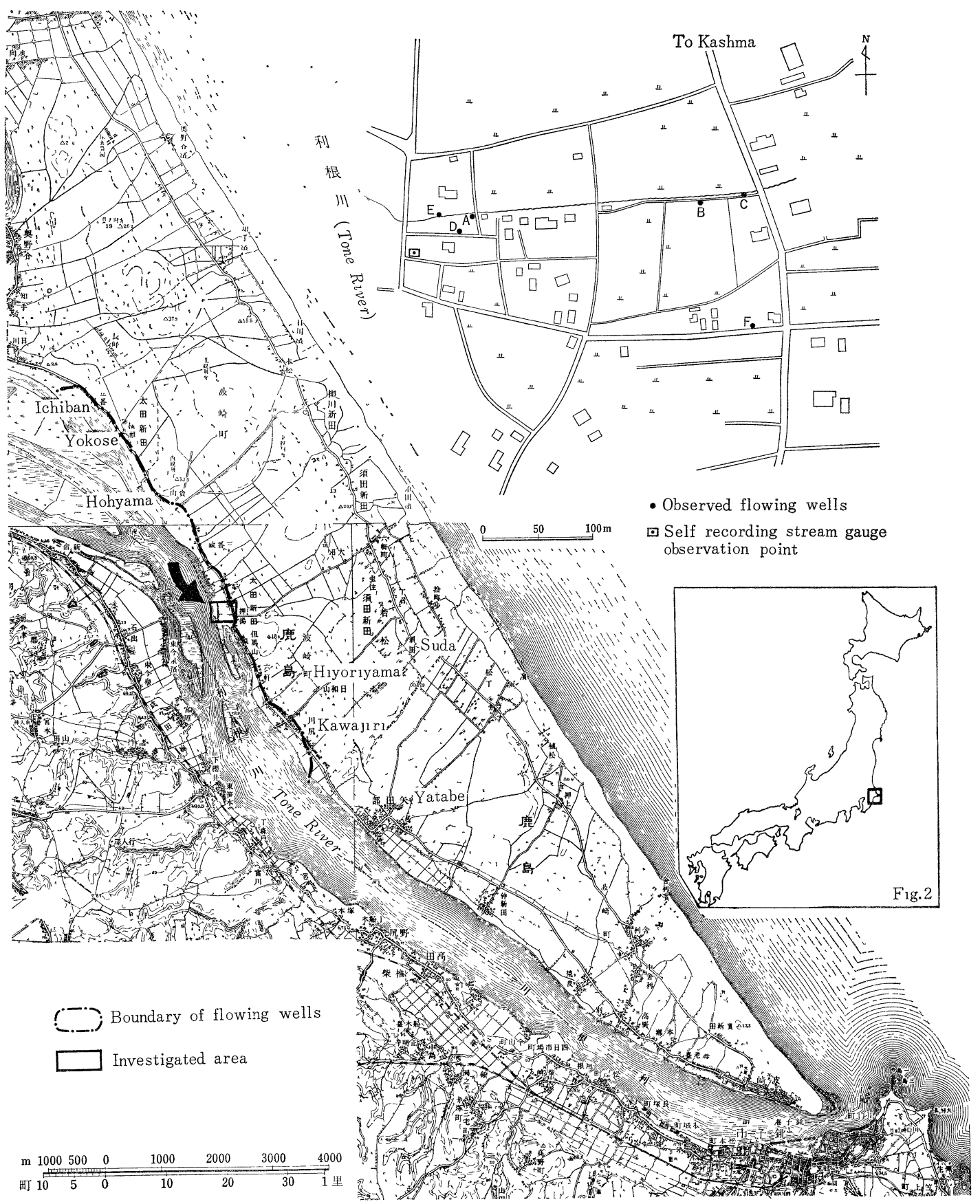

Fig. 1 Studied area, Kashima Pcninsula, Ibarakı Prefecture.

Fig. 2 Detail map for the location of observation wells.

But few studies have been made concerning the changes in the amount of discharge from flowing wells near the bank of a tidal river (Fig. 1). So the writer selected several 
flowing wells in the Kashima-nada coastal region for this study where he had been studying ground water ${ }^{8) 9}$.

\section{General Remarks of the Region}

To investigate the amount of discharge, two flowing wells (A and B) were selected in Ôta-Shinden of Hasaki-machi, Kashima-gun, Ibaraki Prefecture (Fig. 2). The sites and structures of these wells are shown in Table 1 and a detailed map near the wells is shown in Fig. 2. Though the distances of the two wells from the river $(\mathrm{A}: 92 \mathrm{~m}, \mathrm{~B}: 300 \mathrm{~m})$ are

Table 1 Sites and structures of observed flowing wells.

\begin{tabular}{|c|c|c|c|c|c|c|c|}
\hline $\begin{array}{r}\text { observed } \\
\text { flowing } \\
\text { wells }\end{array}$ & owner & address & $\begin{array}{l}\text { distance } \\
\text { from Tone } \\
\text { River } \\
\quad(\mathrm{m}) \\
\end{array}$ & $\begin{array}{c}\text { depth of } \\
\text { flowing } \\
\text { wells } \\
\text { (m) }\end{array}$ & $\begin{array}{c}\begin{array}{c}\text { diameter } \\
\text { of pipe } \\
(\mathrm{mm})\end{array} \\
\end{array}$ & $\begin{array}{l}\text { the length of pipe } \\
\text { above ground sur- } \\
\text { face } \quad(\mathrm{m})\end{array}$ & $\begin{array}{l}\text { ground } \\
\text { height } \\
\text { (m) } \\
\end{array}$ \\
\hline A & $\begin{array}{l}\text { Genzo } \\
\quad \text { Suzuki }\end{array}$ & $\begin{array}{l}\text { 260-7, Ohta, Hasaki- } \\
\text { cho, Kashima-gun, } \\
\text { Ibaraki Pref. }\end{array}$ & 92 & 17.37 & 75 & 0.71 & 2.30 \\
\hline B & $\begin{array}{l}\text { Matao } \\
\text { Nagasaku }\end{array}$ & " & 300 & 7.32 & 75 & 0.70 & 2.80 \\
\hline
\end{tabular}

not ideal for this kind of study, they have some advantages, because there is a gauge station of river water level (Ôta-Shinden Water Level Gauging Station of the Ministry of Construction). The station is situated $15.5 \mathrm{~km}$ from the mouth of the River Tone. As a general description of geology and geomorphology of Kashima Peninsula has already been made in the writer's previous paper, the details are not presented here.

The distribution of the flowing wells is limited to the river side where the alluvial deposits of the former Tone River are found. The area is shown by a dotted circular line in Fig. 1. Most of the wells are situated along the River Tone near the prefectural road from Kawajiri to Ôta-Ichiban, and their altitudes are less than $3 \mathrm{~m}$ above sea level. The fact that the distribution of the flowing wells is limited to this district seems to be closely related to the distribution of old sand dune groups. For example, several sand dunes crossing the peninsula at the point between Yatabe and Kawajiri run form the point eastward to Suda, or along the prefectural road from Hiyoriyama to Ichiban through Tajimayama, Hôyama and Yokose. These sand dunes surround the flowing well district, and large scale semicircular sand dunes also develop in the middle of the peninsula. In this district, the depth of the flowing wells is more than $4 \mathrm{~m}$ below the surface in general. This fact may be due to geological conditions rather than geomorphological ones mentioned above.

Fig. 3 is a shematic columnar section of geological structure from the core sample of Well E located near the River Tone. It indicates that along the River Tone silty sand and sandy silt layers of alluvial deposits are interbedded as a lenticular bed among the sand and gravel layers. So the ground water must be partially confined. According to the data already obtained,

8) Takamura, Hiroki (1963): The Free Ground Water Surface in Kashima Peninsula (1). Journal of the Faculty of Literature of Rissho University, Vol. 17, pp. 24-44.

9) Takamura, Hiroki (1967) : Electrical Conductivity of Ground Water-A Case Study in Kashimanada Coastal Region. Suion-No-Kenkyu (Water Temperature Research), Vol. 10, No.6, pp. 15-19. 
silty sand and sandy silt layers lie at the depth of $2-3 \mathrm{~m}$ below the suface, and silty sand or clay sand layers are at the depth of $8-10 \mathrm{~m}$. Though the ample ground water existed at the depth of 4-5 m, the amount of present discharge from the artesian wells has diminished as a result of over pumping for irrigation. Consequently, the depth of wells for domestic use has been increased year by year to as deep as $10-12$ or even $16 \mathrm{~m}$ below the surface. For agricultural use, wells of $30 \mathrm{~m}$ depth such as Well $\mathrm{E}$ are not exceptional today.

\section{Method}

Observations were made on the annual and diurnal changes of the discharge from flowing wells. For Well A, every 12 hours' flow was observed at $6: 00$ and 18:00 for 15 months. On Wells $\mathrm{A}$ and $\mathrm{B}$, the diurnal changes were observed every 10 minutes (at the second time, every 20 minutes) throughout the 24 hours.

Concerning the method of estimating discharge, there are notch method, theoretical method using hydrostatic pressure and so on $^{10) 11}$. In this study the writer had to take a simple method so as to preserve the present conditions of wells, because theses wells were in use. So measurements were carried out in two ways; one is to measure the time for the flowing water to fill in a bucket at its exact full capacity and the other is to measure the rate of discharge in five seconds. As a result it was manifested that the former had rather large errors of measurement because of bubblings, and the latter was adopted ac-

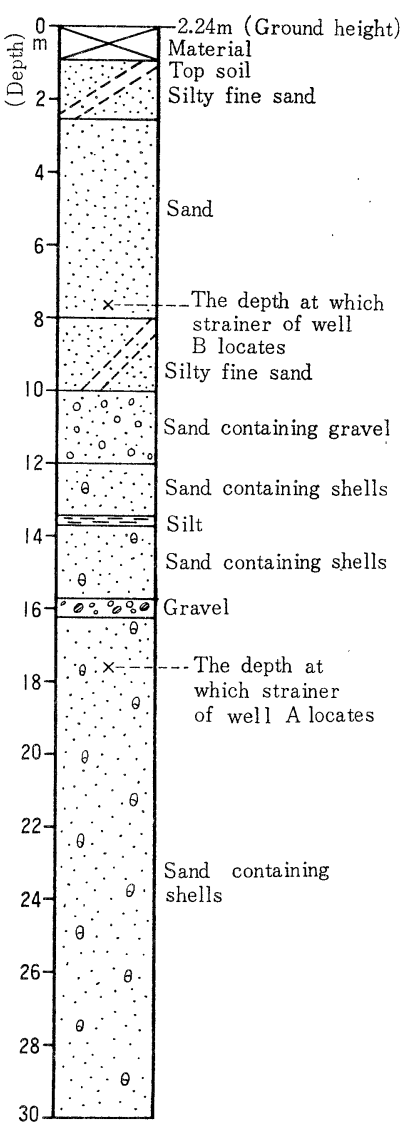

Fig. 3 A colunmar section in the neighbourhood of driller's flowing well E. ordingly. The flow was measured using a stop watch and 2,000 $\mathrm{ml}$ measure cylinders. Each measurement was made two times, and the mean of the two was adopted as a representative value of discharge per minute.

The relations of discharge with the river water level and precipitation are shown in the observed data. Comparing the precipitation of Chôshi (from $0: 00$ to $24: 00$ ) with that of Sasa-

10) Sasashima, Sadao (1960): On the Flow Capacity of Artesian Aquifer.—A Case of Tsuruga Plain, Fukui Prefecture, Chigaku-Zasshi (Journal of Geography), Vol.69, No. 1, pp. 32-35.

11) Nomitsu, Ryûji et al. (1940) : Tikyu’butsuri (Journal of Geophysics), Vol.2, No. 1, p. 12 . Assuming that discharge $q$ varies with hydrostatic pressure, he deduced the following equation:

$$
q=\frac{C}{g_{1} e} a\left(P-P_{l}\right)
$$

where $C$ is a coefficient, $g_{1}$ gravity acceleration, $e$ the specific gravity of the hot spring water, $a$ area of the pipe, $P_{0}$ hydrostatic pressure and $P_{l}$ water pressure at the top of well mouth.

Supposing $P_{0}$ changes with tidal level $H$, rearranging

$$
P_{0}=\lambda g_{1} e H \quad \text { and } C \fallingdotseq 1
$$

therefore $C \lambda=h / a$ where $\lambda$ is a constant. 
gawa (from $9: 00$ to $9: 00$ ), there found scarcely any differences, and so the writer used the former data which seem to be adequate for the compaison with the discharge. The writer also used the data of the river water level from August in 1967 to June in 1968 which had been observed by the Ôta-Shinden Gauging Station of the Ministry of Construction, and the data for July in 1968 will be used in the next work. As artesian wells are located within the distance of less than $300 \mathrm{~m}$ from the river bank, and the influences of precipitation and the river water level on the discharge from wells are marked, it may be said that influence of atmospheric pressure is negligible ${ }^{12}$.

Although investigations had been made on the distribution of the artesian flowing wells in this district by the writer from 1961 to $1965^{13)}$, he re-investigated the boundary of area of flowing wells (Fig. 1) as well as their structures and functions in July 1967. Among the wells (Fig. 2), Wells $\mathrm{A}$ and $\mathrm{B}$ were selected for this study, because the others nearby (C, D, E, F) have almost the same charcters as $\mathrm{A}$ and $\mathrm{B}$.

The obervation period was as follows : 1) annual changes of discharge form Well A ; from August 1, 1967 to July 31, 1968, 2) diurnal changes of discharge from Wells A and B; two times, 24 hours from $9: 20$, October 13, 1967 and from 21:00 July, 12, 1968.

\section{The Results}

IV-1 Changes in the discharge from flowing wells

The results of the observation for Wells $\mathrm{A}$, observed twice a day at $6: 00$ and $18: 00$ during 12 months, are shown in Figs. 4-1, 4-2 and 4-3, where $t$ is the time of the observation, and $Q$ denotes the amount of discharge. The ordinate of Figs. 4-1, 4-2 and 4-3 shows the amount of discharge $(1 / \mathrm{min}$, at $6: 00$, at $18: 00)$ the river water level $(\mathrm{cm}$, the mean value of level at $6: 00$ and $18: 00)$ and precipitation $(\mathrm{mm})$, and the abscissa shows dates. There is a difference in the discharge measured in the morning and that in the evening. The writer guessed that this difference was due to the influence of the tide and estimated the each day's mean discharge as shown in Table 2.

12) According to the paper cited ${ }^{4)}$, at a hot spring near the coast in Beppu (the distance from the sea is $42 \mathrm{~m}$.) the discharge varies with tidal fluctuation and there is a positive correlation between them which is expressed in the form of

$$
\frac{\partial q}{\partial H}=h
$$

where $h$ is a constant called the tidal coefficient. On the other hand, in a hot spring located further from the sea $(320-820 \mathrm{~m}$. away from the sea), there is a negative correlation between discharge $q$ and atmospheric pressure $P$ as follows :

$$
\frac{\partial q}{\partial P}=-p
$$

in which $p$ is the constant called atmospheric coefficient. From these two equations, discharges $q$ can be written as:

$$
q=h H-p P+C
$$

The above equation suggests that the influence of atmospheric pressure upon discharges can be neglected at those hot springs which are situated in the vicinity of the coast within the distance of 30 meters from the sea.

13) Takamura Hiroki (1965): On the Hydrological Balance in the Southern Region of Kashima-gun, Ibaraki Prefecture (résúme), Chirigaku-Hyôron (Geographical Review of Japan), Vol. 38, No.6, pp. 17-18. 


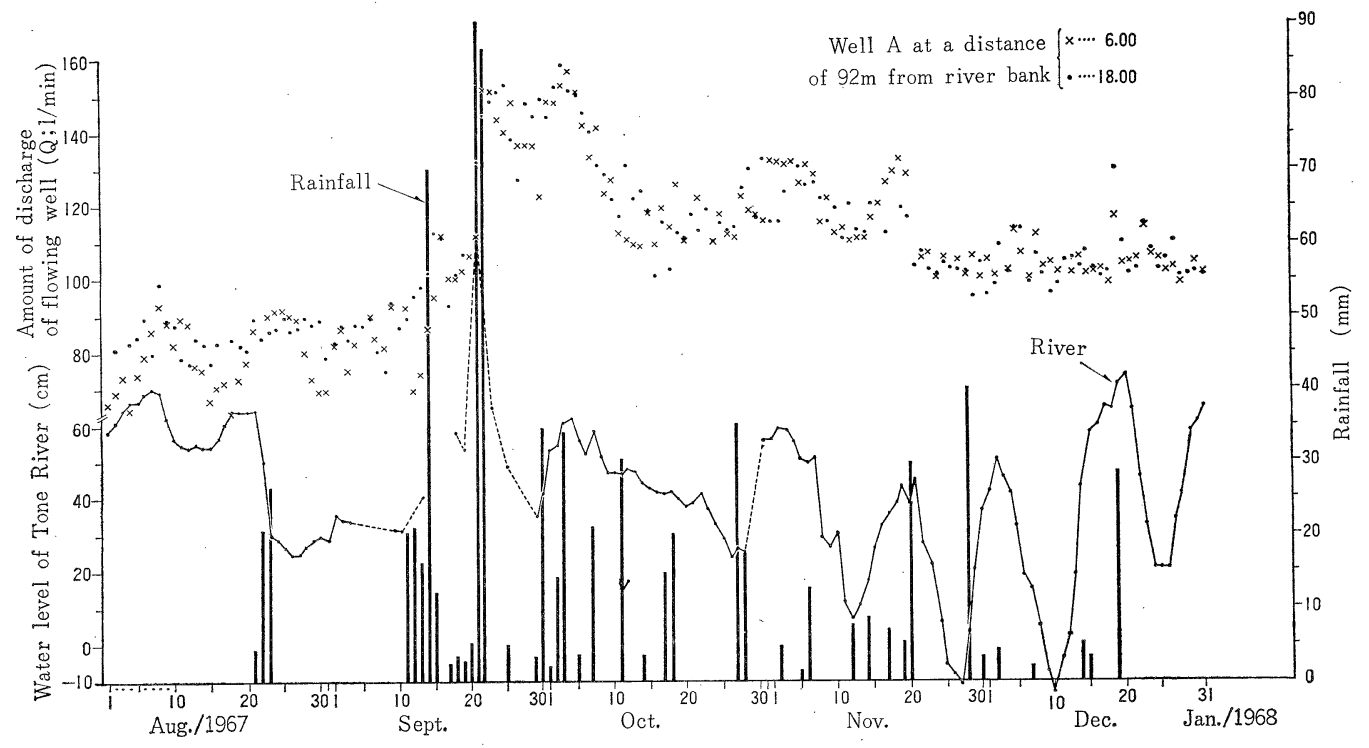

Fig. 4-1 Relation between the discharge of the observed flowing well and river water level, daily rainfall. (8.1, 12.31, 1967)

Monthly fluctuations in discharge of flowing well A at 92 meters distance from left bank side influenced by seasonal condition, daily rainfalls and yearly variation on water level of the Tone River.

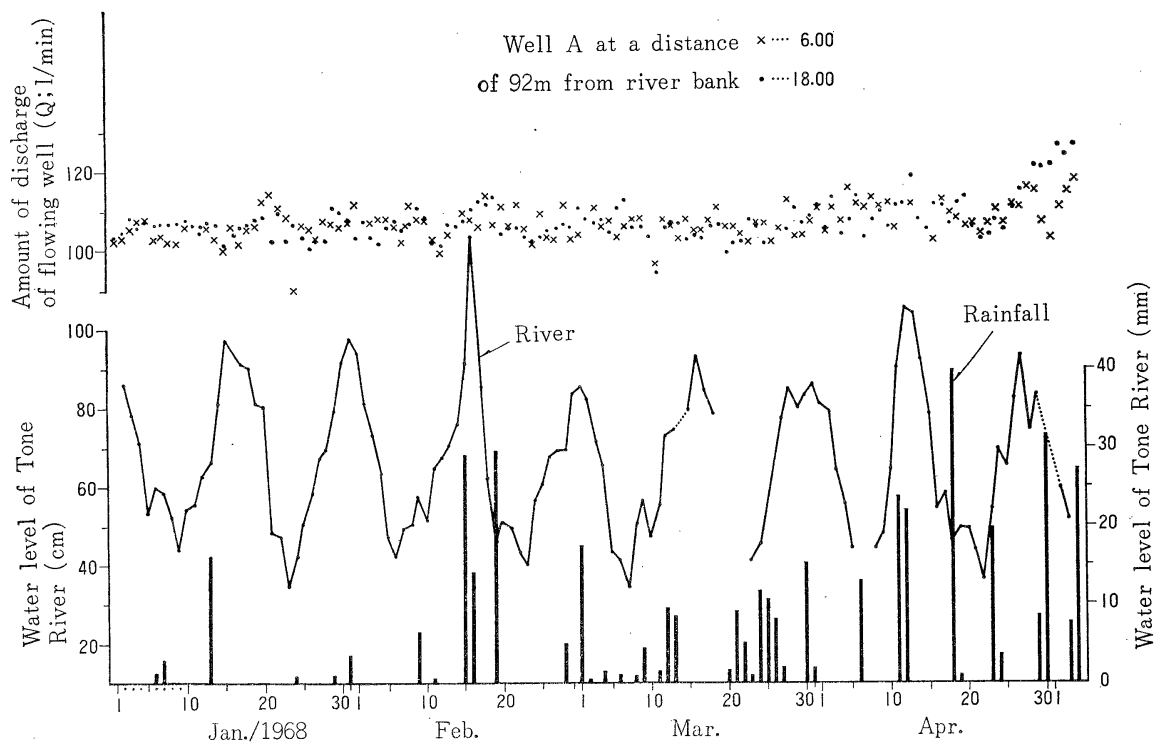

Fig. 4-2 Continued (Jan. 1, May. 4, 1968)

The results of obeservation for Wells A and B for 24 hours are shown in Figs. 5 and 6. The first obervation was made in October, 1967, when the maximum of mean monthly discharge occurred. The second observation was made in July, 1968 (when the median of mean monthly discharge occurred). It was shown that the discharge had a tendency to decrease. 
Table 2 Amplitude on deviation of amount of discharge of flowing Well A (1967 1968).

\begin{tabular}{|c|c|c|c|c|c|c|c|c|c|c|c|c|}
\hline \multirow{3}{*}{ Day } & 8 月 & 9 & 10 & 11 & 12 & 1 & 2 & 3 & 4 & 5 & 6 & 7 \\
\hline & ave. & ave. & ave & ave. & ave. & ave. & av & ave. & ave. & ave. & ave. & ave. \\
\hline & $(l / \mathrm{min})$. & & & & & & & & & & & \\
\hline 1 & - & 82.44 & 34 & 124.00 & 100.56 & 90 & 07.40 & 107.28 & 110.70 . & - 106.92 & 116.94 & 113.9 \\
\hline 2 & 75.00 & 87.18 & 150.18 & 123.78 & - 99.90 & 103.74 & 107.34 & 107.70 & 104.82 & 113.46 & 123.36 & 118. \\
\hline 3 & - & 79.20 & - 155.58 & 127.56 & - & 106.80 & 104.76 & 105.51 & 112.08 & 114.60 & 141.90 & 117.2 \\
\hline 4 & 73.32 & 85.11 & 154.14 & - & 101.76 & 106.56 & 104.28 & 106.50 & 105.38 & 117.12 & 111.30 & 113. \\
\hline 5 & 79.08 & 87.00 & 150.54 。 & - 128.22 & 114.18 & 107.40 & 106.56 & 105.60 & 111.60 & 118.98 & 114.46 & 118.2 \\
\hline 6 & 84.36 & 89.40 & 143.52 & 128.64 & 110.85 & 104.64 & 106.44 & 106.68 & 112.44 & 116.88 & 109.62 & - \\
\hline 7 & 82.71 & 82.08 & 136.53 & $127.688^{\circ}$ & - 99.90 & 105.27 & $103.44 \circ$ & - 109.20 & 106.74 & 112.74 & 109.98 & 113.8 \\
\hline 8 & 95.85 。 $^{\circ}$ & 78.18 & 136.02 & 118.62 & 109.62 & 104. 34 & 108.84 & 106.56 & 110.40 & 119.22 & 110.04 & - \\
\hline 9 & 88.35 & 30 & .76 & 118.89 & 102.76 & 104.34 & 109.08 & 106.68 & 110.16 & 111.42 & 108.27 。 & - 118.9 \\
\hline 10 & 84.90 & 86.34 & 38 & 116.04 & 100.74 & 47 & 107.52 & 103.32 & 108.66 & 108.42 & 108.06 & 115. \\
\hline 11 & 83.88 & 90.90 & 114.69 & 112.44 & 100.50 & 106.47 & 101.88 。 & 95.10 & 108.10 & 113.82 & 114.12 & 118.0 \\
\hline 12 & 82.41 & 82.50 & 12 & 115.14 & 105.72 & 105.07 。 & 99.84 & 106.86 & 111.36 & $113.52 \circ$ & 104.40 & 106.8 \\
\hline 13 & 80.07 & 85.92 & 115.45 & 112.44 & 103.80 & 106.35 & 105.00 & $106.44{ }^{\circ}$ & - 114.72 & - 124.56 & 122.70 & - \\
\hline 14 & 78. 75 & 41 & 68 & 111.78 & 105.06 & 40 & 78 & 104.76 & 107.46 & 122.40 & 68 & 109.2 \\
\hline 15 & 71.91 & 101.10 & 118.68 & 118.62 & 104.58 & & & 105.24 & 105.54 & 122.22 & 114.27 & 105. \\
\hline 16 & 76.71 & $111.780^{\circ}$ & 105.18 & 118.50 & 102.60 & 104.42 & 10 & 103.68 & & & 109.74 & 106.68 \\
\hline 17 & - & 51 & & & 102 & 103.47 & 108.90 & 103.68 & 111.84 & 111.48 & 118.32 & 104.8 \\
\hline 18 & 73.53 & 100.69 & 108.30 & 122.64 & 100.68 & $105.90^{\circ}$ & & 106.56 & 107.82 & 106.08 & 115.95 & 104.3 \\
\hline 19 & .19 & 61 & & 126.42 。 & - 123.78 & 106.74 & 109.68 & 108.54 & 108.80 & 107.34 & - & 99.9 \\
\hline 20 & 78.84 & 106.67 & 110.70 & 122.94 & $107.40^{\circ}$ & - 110.40 & & 102.60 & 109.80 & 120.54 & 128.46 & 101.52 \\
\hline 21 & 87.72 & 120.18 & 116.22 & - & 103.20 & 108.18 & 105.96 & 103.74 & 105.96 & 50 & $123.06 \circ$ & 92.88 \\
\hline 22 & .79 & 147.72 & 117.75 & 106.74 & 104.22 & 110.04 & 108.48 & $102.72 \circ$ & - 102.84 & 117.54 & 115.50 & 98. \\
\hline 23 & 88.29 。 & 149.82 & 117.66 & 105.12 & 105.08 & 105.15 & 104.04 & 104.64 & 104.70 & 119.82 & 111.30 & 103.50 \\
\hline 24 & .07 & & 109.59 。 & 。 100.86 & $107.70^{\circ}$ & 98.04 & 101.82 & 106.14 & 108.90 & 111.60 & 109.02 & 92.8 \\
\hline 25 & 90.45 & 146.40 & 116.73 & 105.42 & 104.34 & 104.70 & 106 & 103.86 & 105.90 & 118.26 & 121.92 & 94.0 \\
\hline 26 & 87.81 & & 112.80 & - & 104.04 & 102.90 & 10 & & 110.88 & 111.84 & 122.52 & 98.70 \\
\hline 27 & 87.84 & & 112.74 & 104.04 & 107.10 & 102.03 & 103.92 & 105.24 & 112.92 & 121.08 & 140.22 & 97.68 \\
\hline 28 & 84.72 & 142.38 & 128.87 & 101.82 & 100.20 & 104.70 & 108 & 108.76 & 115.86 & $113.82 \circ$ & - 150.60 & 104.04 \\
\hline 29 & 80.31 & & 124.44 & 100.74 & 101.46 & 108.63 & 103 & 106.98 & 112.98 & 118.62 & 114.90 & 98.94 \\
\hline 30 & 78.99 & 136.08 & 117.00 & 102.72 & 103.80 & 107.28 & & 104.88 & 108.66 & 120.93 & 125.94 & 100.08 \\
\hline 31 & 73.89 & & 124.38 & & 102.12 & 107.28 & & 107.52 & & 126.57 & & 105. \\
\hline 計 & $2,250.64$ & To & 00 & & 39 & $3,265.17$ & 0 & 31 . & $3,274.88$ & 0,002 & $3,435.55$ & $2,972.2$ \\
\hline $\bar{M}$ & 79.30 & 107.68 & 124.78 & 115.60 & 104.65 & 105.33 & 106.23 & 105.31 & 20.20 & 115.90 & 118.47 & 106.1 \\
\hline $\mathrm{Q} l$ & $(-) 7.39$ & $\Rightarrow 29.50$ & & & & & & 10.21 & $6.32 k$ & & & 13.2 \\
\hline$\triangle Q h$ & 16.55 & 42.14 & +) 30.80 & +) 12.62 & t) 19.13 & $\Rightarrow 5.07 \mathrm{~s}$ & & & 0.00 & & $\Rightarrow 32.13$ & 12.83 \\
\hline$\triangle Q$ & 23.94 & 71.64 & 50.40 & 27.36 & 23.88 & 12.36 & 12.54 & 14.10 & 11.88 & 17.64 & 46.20 & 26.10 \\
\hline
\end{tabular}

$\bar{M}$ : Monthly average.

$\triangle Q l$ : the difference between the average and lowest water discharge.

$\triangle Q \mathrm{~h}$ : the difference between the average and high est water discharge.

$\triangle Q$ : Amplitude on deviation of amount of discharge.

- : Maximum and minimum of amount of discharge.

\section{IV-2 Changes in River Water Level and the Amount of Precipitation}

The water level in the River Tone and the amount of precipitation ( $\mathrm{mm} /$ day) are illustrated in Figs. 4-1, 4-2 and 4-3 respectively. According to these figures, the water level of the Tone changes four times a day following the tidal change. It also generally corresponds 


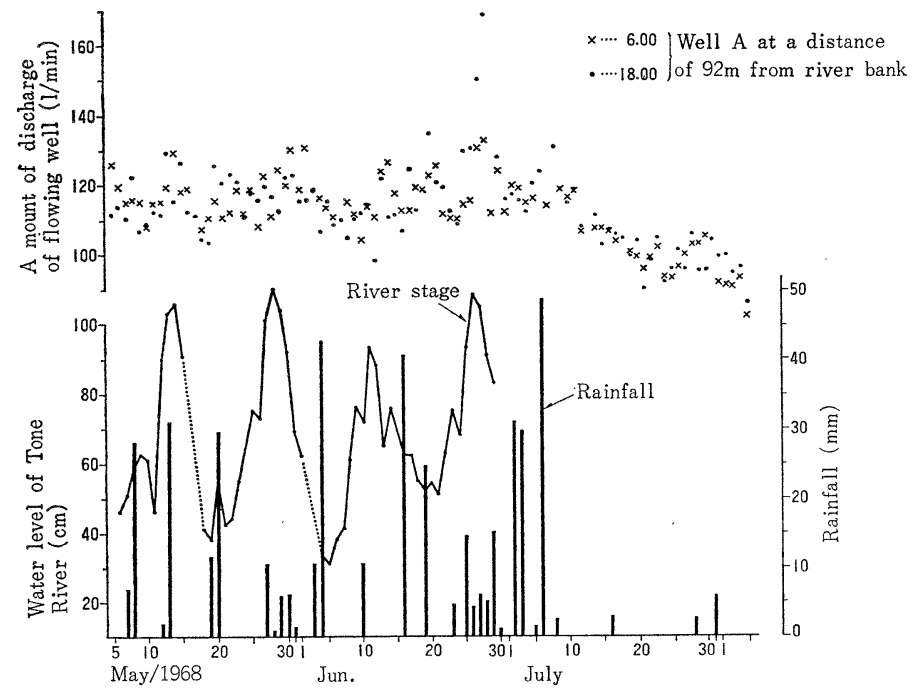

Fig. 4-3 Continued (5.5, 7.31, 1968)

to the amount of precipitation. However, there are some exceptions. For example, though the precipitation of about $51 \mathrm{~mm}$ was recorded from August 21st through 23rd, the water level diminished $32 \mathrm{~cm}$ on Aug. 21st and 22nd. This means that the water level of the Tone does not necessarilly correspond with the amount of precipitation of this district. But generally speaking, it does correspond showing a 24 hours' time lag.

\section{Infiuence of River Water Level and Precipitation on Discharge}

Though the river water level sometimes decreases without relating to precipitation, it shows regular variation of a rather large scale during the period from November to December when they have comparatively little precipitation. From this phenomenon, it may be said that in the rainy season the changes in river water level are affected mostly by the precipitation but less by the tide, and in the ordinary season they are affected by the tide. Now the relation between the water level of tidal river and the precipitation, and the relation between the water level and the changes in discharge from artesian wells are to be stated as below.

Firstly, the amount of discharge varies in proportion to the distance from the river bank as shown in Figs. 5 and 6 . The discharge from Wells A and B shows a cyclic change with two maximums and two minimums in a day, and it is similar to that of the river water level. This clearly shows the influence of the water level of the River Tone, the lower course of which is sensitive to tidal change. Changes of Well A which occur every ten minutes (=amplitude) are larger than those of $\mathrm{B}$; that is, Well $\mathrm{B}$ is not so much influenced by the changes of the tidal river water as in the case of Well A. The same phenomenon is seen in Fig. 6. The river water levels in this figure were derived from the data of tidal level (Table of Tidal Level) at Chôshi (a fishing port), because at Ôta-Shinden the hourly data of the river water level had not 


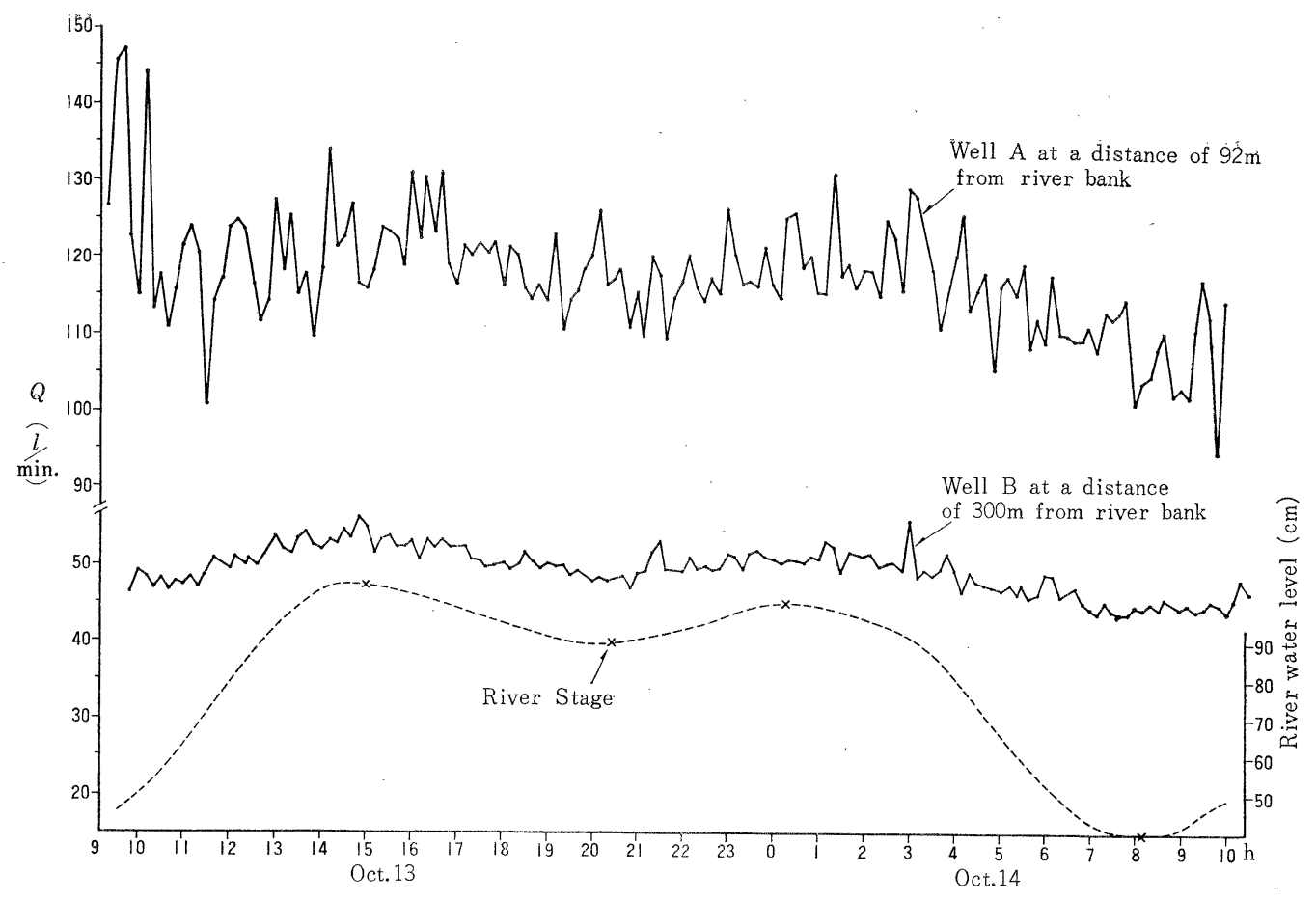

Fig. 5 Hourly fluctuation in discharge of flowing wells at various distance from the river Tone. (October 13 14, 1967)

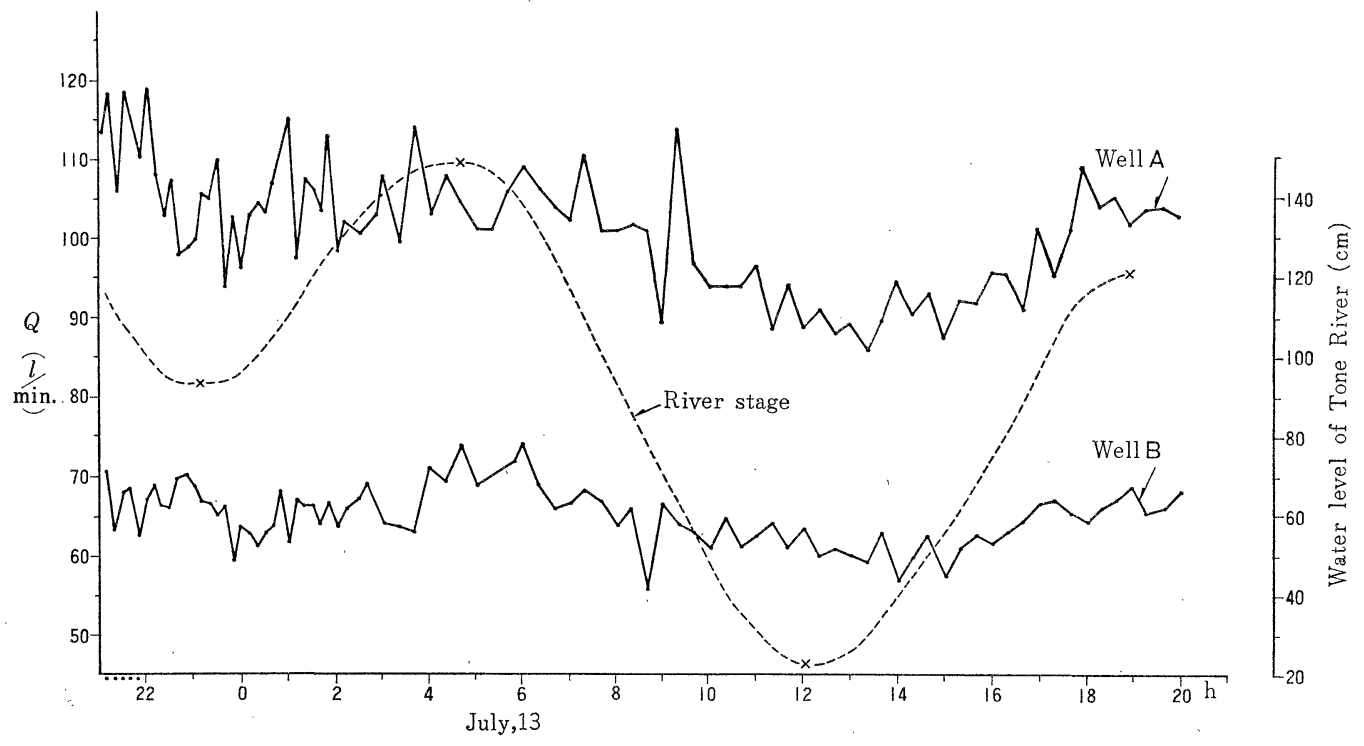

Fig. 6 Hourly fluctuation in discharge of flowing wells at various distance from the Tone River. (July 12 13, 1968) 
yet been published. If the hourly record of water level were available, the sine curves could be constructed acording to those data by means of moving average or sectional average, and half a day tide could be caclulated by the river water level. The discharge from Wells A and $\mathrm{B}$ and the diminishing rate of the changes in discharge according to the distance from the river bank could also have been worked out. To investigate the reliable time lag, at least more than three wells are necessary if the area is of complex geological structure ${ }^{14) 15) 16}$. It seems that the same thing is seen in the well water level at Honmura in Izu Nii-jima, south of Tôkyô. Fig. 7 shows the relation between tidal level and hourly ground water table at Nii-jima. A dotted line is the fluctuation of ground water table by the influence of tidal level in a well at 100 meters distance from shoreline. The reference level is 9 meters deep from ground surface. A solid line is the fluctuation of tidal level. There, the ground water stratum is entirely composed of tuffacious sand and gravels called the Shiromama Stratum. Werner ${ }^{17)}$ refers in his

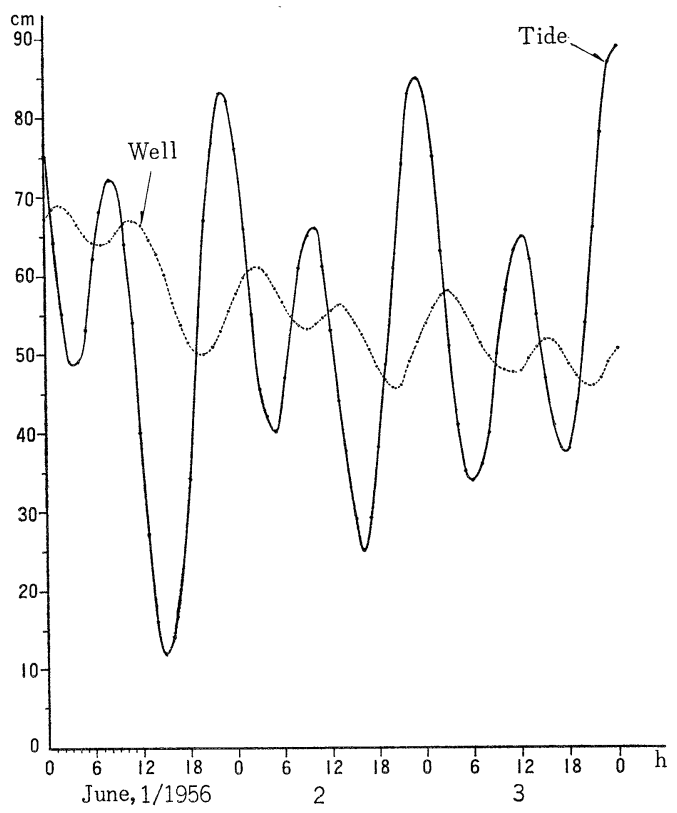

Fig. 7 Relation between tidal level and hourly ground water level at Niijima, Izu Island groups.

Fluctuation of ground water table by the influence of tidal level in a well at 100 meters distance from shore-line, the reference depth is 9 meters from ground surface.

14) In S. Yamamoto's paper (1968) the time lag was not recognized. The study clarified the influence of land reclamation by drainage of Tôgô Pond in the hot-springs of Matsuzaki, Tôgô and Asazu. Rikusuigaku-Zasshi (The Japanese Journal of Limnology), Vol. 29, No. 1, pp. 1-12.

15) In the article of op. cit. 5), p. 12, in Beppu the time lag is not recognized also.

16) In the article of op. cit. 6), the estimations of the time lag are given using following relationship:

$$
\begin{aligned}
& P_{0}=\lambda q_{1} e H \cdots \cdots \cdots \cdots \cdots(\mathrm{a}) \\
& C \lambda=h / a \cdots \cdots \cdots \cdots \cdots(\mathrm{b})
\end{aligned}
$$

These equations represent the effect of tidal fluctuation exerting as sea water pressure upon discharge. However, as this effect cannot be estimated in the form of product which equals to $h / a$.

17) Werner P. W. (1915) : Progressive Waves in Non-artesian Aquifers, Trans. Amer. Geoph. Union, Vol. 32 , No. 2, pp. $238 \sim 244$. 
work to E. Prinz's study of ground water level in the Elbe Valley ${ }^{18)}$ which has 13 observation points $300-4,000 \mathrm{~m}$ away from the river bank. According to Prinz's study, the water level of the Elbe changes with a cycle, of about 9 days with increase and decrase 4 times a day. The amplitude of changes with half a day cycle decreases clearly in proprotion to the distance from the river as shown in Wells I and II, which are $300 \mathrm{~m}$ and 1,200 $\mathrm{m}$ away from the river respectively. This is similar to the water level of the Elbe. But at Wells III, IV and XIII, located 1,500 m, 2, $750 \mathrm{~m}$ and 4,600 $\mathrm{m}$ from the river respectively, no cyclic change is found. While the cycle of every 9 days is seen also in Well XIII, the fluctuation decreases in proportion to the distance from the river. The time lag at XIII is about 2 days.

Now the relation among the river water level, rainfalls and the changes of water yield are to be clarified by comparing them.

Figures 4-1, 4-2 and 4-3 show the changes in discharge where $\mathrm{X}$ marks indicate those at $6: 00$ in the morning and dots for those at $18: 00$ in the evening. Though any regular fluctuation of the water yield in the day and in the evening is recognized, it may be said that from August 1 to September 20, the discharge in the evening is greater than that in the morning, and from October 14 to December 13, the inverse tendency can be recognized. On the other hand, when the difference between the discharge in the morning and evening is large, the quantity in the evening is often larger than that in the morning. Thus the difference of the discharge in the morning and evening seems to be related to tide. But the influences of the river water level ${ }^{19}$ ) and the precipitation cannot be easily taken separately ${ }^{20)}$.

The following cases seem to be the result of the substantial increase of amount of discharge due to precipitation. Firstly, on August 22nd and 23rd, there was comparatively large amount of water notwithstanding the low water level of the river. Secondly, the discharge increased from the end of August to the beginning of September, with the value of $80 \mathrm{l} / \mathrm{min}$ $90 \mathrm{l} / \mathrm{min}$. In addition to this, the discharge increased further in the period from 21 st to 25 th of September ( $140 l / \mathrm{min}-150 l / \mathrm{min})$.

The cyclic increase and decrease of discharge can be recognized as follows ; Sep. 27 th (130 l/ min, decrease), Oct. 2nd ( $150 \mathrm{l} / \mathrm{min}$, incrcase), the middle of Oct. (decrease), beginning of Nov. (increase) and the end of Nov. (decrease). It is thought to be caused by the tidal change, but as it is also complicatedly influenced by precipitation, the correlation among these fact is not clear. As for tidal influence, in the rainy seasons from September to December in 1967, and from May to the beginning of July in 1968, the river water was affected by the precipitation with the increase of water. Consequently we cannot recognize any tidal influences.

18) Prinz, E. (1923) : Hydologie, Springer Verlag, Berlin, p. 100.

19) The paper, op. cit. 14), p.11,

$$
\frac{\partial Q}{\partial h}=\frac{2 \pi K D}{\ln \left(R / r_{0}\right)} \lambda \quad \therefore \lambda K D=\frac{2.3 \log _{10}\left(R / r_{0}\right)}{2 \pi} \cdot \frac{\partial Q}{\partial h}
$$

provided that, $R$ : radius of the affected districts, $K$ : coefficient of permeability of well, $D:$ thickness of the aquifer.

20) Seno (1940) : attempted to analyze the correlation of discharge to tidal fluctuation. However, his attempt failed because of observational error. In spite of this, the influence of tidal fluctuation upon discharge could be neglected if the average of the monthly record is adopted, therefore the increment of discharge derived from precipitation could be estimated indenpendently. 
While in the months of scarce precipitation (from January to April), the influence of the tide upon water level can be seen clearly. When the river water level increases affected by precipitation, two types of curve are seen i. e. the sharp one and the mild one, and it is due to the geological conditions and the water bearing of the soil in the area, to which type of curves it belongs.

According to Kinzô Seno ${ }^{21}$, in each case the decreasing curve of the increased amount of discharge due to the rainfall $R, \Delta q_{a}$ is : $q=\Delta q_{a} e_{-c 1 t}+q_{o}, \frac{d\left(\Delta q_{a}\right)}{d t}=-c_{1} \Delta q_{a}$.

The extent of the change in amount of discharge in this district is large in the months from August to December (Fig. 4-1) and from May to June (Fig. 4-3), showing the discharge of $65 \mathrm{l} / \mathrm{min}-160 \mathrm{l} / \mathrm{min}$ in the former case, and $80 \mathrm{l} / \mathrm{min}-170 \mathrm{l} / \mathrm{min}$ in the latter, and it is small during the months from January to April (Fig. 4-2) when the quantity is $100 \mathrm{l} / \mathrm{min}-120$ $l / \mathrm{min}$.

Seno showed monthly variation range of water yield of the wells affected by the tide in Beppu Hot Springs ${ }^{22)}$.

$$
\text { Amplitude }=\frac{\pi}{2} \cdot \frac{1}{n} \sum_{i=1}^{n}\left|1-\frac{\text { amount of discharge }}{\text { monthly mean quantity }}\right|
$$

From this, it is recognized that as linear distance from the sea increases, the range of amplitude decreases independently of the water yield. The same was recognized in Wells A and $\mathrm{B}$ in this district (Fig. 5, Fig. 6), but the writer could not recognize any time lag.

As the amount of discharge from flowing wells is affected in the same manner as the ground water changed by the water level of lakes, sea and rivers, there are two causes of the rise and fall of the ground water table; one is due to squeezing out of ground water in the aquifer and the other is due to the increase of ground water pressure. As for the latter, Sôki Yamamoto ${ }^{23)}$ calculates the degree of the influence by the coefficient of influence $\frac{\partial Q}{\partial h}$ of the amount of discharge $Q$.

The amount of discharge which increased by precipitation decreases from October 4 th to 16 th and from July 9 th to 21 st, and in both cases the phenomenon of decrease ceases in 12 days.

As to the amount of discharge from flowing wells and the river water level, the mean of the two observational data in a day was used, as the daily mean and the monthly means were taken from the total of these daily means. Fig. 8 are relationship between monthly fluctuation of average amount of discharge in the flowing Well A which locates $92 \mathrm{~m}$ from the river bank, variation of mothly average of water level of the Tone River, and monthly total rainfalls, during the period from August 1967 to July 1968.

In Fig. 8 (the monthly water yield, the river water level and precipitation) there can be seen the seasonal changes, although the changes of the mean water yield show the small amplitudes due to the influence of the tide. That is, three periods of ordinary, high and low water flow can be distinguished. August $(79.3 l / \mathrm{min})$ belongs to the low, May $(115.9 \mathrm{l} / \mathrm{min})$, June $(118.5 \mathrm{l} / \mathrm{min})$, October $(124.8 \mathrm{l} / \mathrm{min})$ and November $(115.6 \mathrm{l} / \mathrm{min})$ belong to the high,

21) op. cit. 20), $C_{1}$ : decreasing coefficient.

22) op. cit. 5), p. 25, Fig. 1.

23) op. cit. 14). 


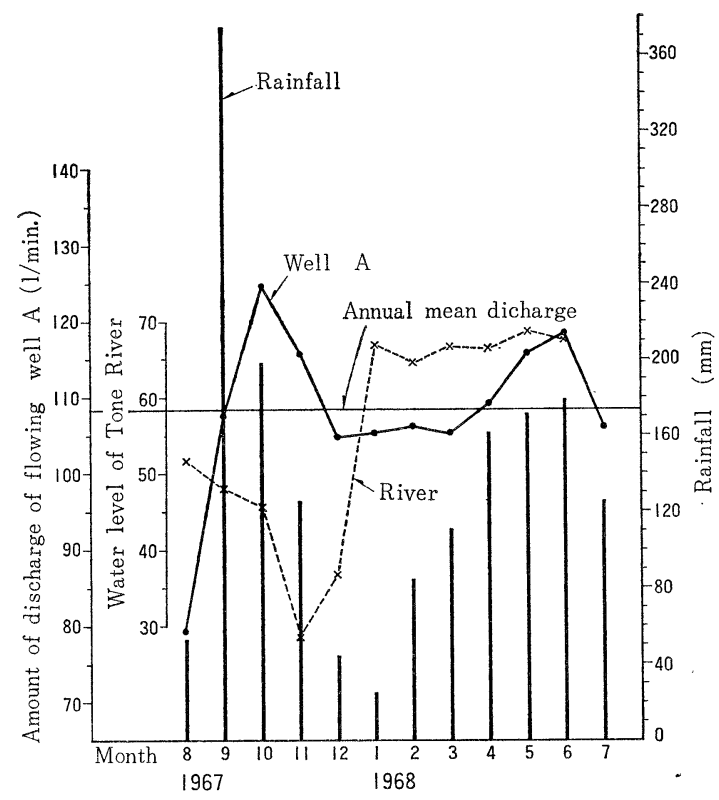

Fig. 8 Relationship between monthly fluctuation of mean discharge in flowing Well $\mathrm{A}$ at a distance of 92 meters from river bank and variation of monthly mean water level of the river Tone, monthly total rainfalls, during the period from August 1967 to July 1968.

and January (105.3 l/min), February (106.2 l/min), March (105.3 l/min), April (109.2 l/min), July $(118.5 l / \mathrm{min})$, September $(107.7 l / \mathrm{min})$ and December $(104.7 / / \mathrm{min})$ belong to the ordinary flowing period. Seven monthes have more water discharge than the average, and the remaining five have less than the average. Assuming that the amount of discharge from flowing wells in August is a base, the yield of the months larger than the average corresponds to the increment due to precipitation. Therefore, at least in the six months, yields are larger than the average $(108.2 \mathrm{l} / \mathrm{min})$. The influence of the tide may be eliminated and precipitation has probably caused these increases.

In September, we have as much precipitation as in October in Japan, but the amount of discharge at the beginning of September was low. The cause for this low discharge may be explained by the extension of dry season in August, in the spite of the typhoon-like heavy rain on the 14th and 21th of September. Therefore, we can regard September as in the ordinary period. The reason why the water discharge in August was less than those in both January and December which are thought to be as a dry season seems to be the result of evaportranspiration and the excessive irrigations, although there might be other factors. In Fig. 8, the curve of monthly amount of discharge does not agree well with that of the mean monthly river water level. That is, the curve showing monthly change of the precipitation marks its lowest in August and its highest in September and October during the typhoon season, and then it decreases to the dry season i. e. December to March and increases again in May and June. Thus, we can conjecture that the artesian water is derived 


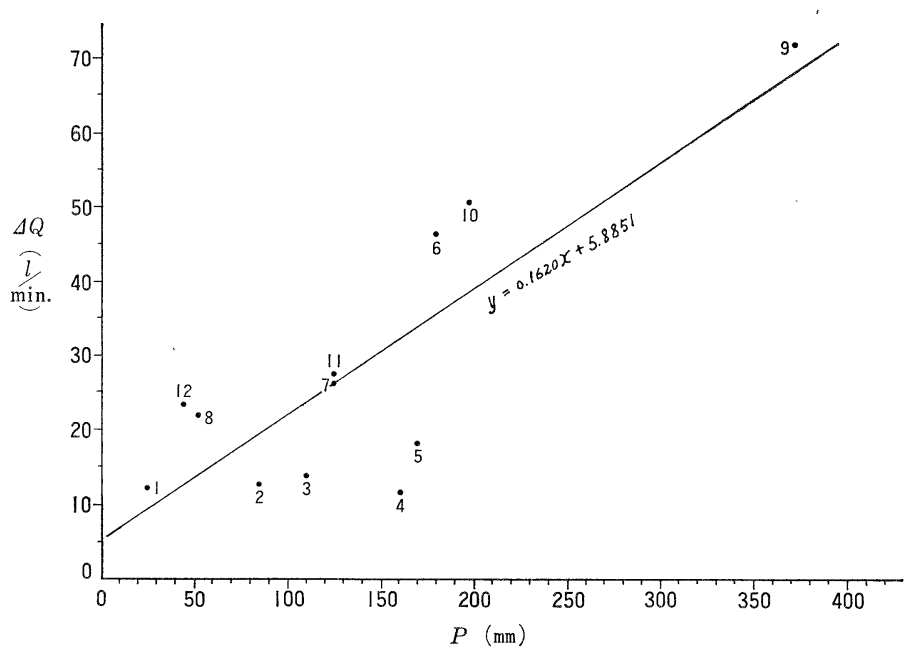

Fig. 9 Relationship between amplitude on deviation $(\Delta Q)$ of monthly average and annual precipitation $(P)$ (in case of flowing well $\mathrm{A}$ ).

from precipitation.

Denoting that $\bar{M}$ equals the monthly average of the amount of discharge per minute, $L_{q}$ : the lowest water discharge in a month, $H_{q}$ : the highest water discharge, $\Delta Q_{l}$ : the difference between the average and the lowest water discharge, $\Delta Q_{h}$ : the difference between the average and highest water discharge, the following equations can be obtained: $\Delta Q_{h}=\bar{M}-H_{q}$, $\Delta Q_{l}=\bar{M}-L_{q}$ Further, if we denote $\Delta Q$ to be the difference between the higest monthly amount of discharge and the lowest, we have: $\Delta Q=\Delta Q_{h}+\Delta Q l$.

In the lower part in Table 2 , the values calculated from these equations are shown. According to the Table $2, \Delta Q_{h}$ in September is the higest, $(+42.14)$, but the $\Delta Q_{l}$ is lower $(-29$. 50) than those of other months.

The relation between amount of discharge and precipitation is additionally illustrated by the diagram which expresses the relationship beween $\Delta Q$ and $P$. (Fig. 9). From this diagram, generally speaking, the correlation of precipitation to amount of discharge is closer in those rainy months as in June, September and October than in the months with little precipitation. The fact indicates that the precipitation in the rainy season has more effective influence upon amount of discharge than other factors, and in the dry season other factors are more effective than the precipitation upon them.

\section{Acknowledgement}

The author wishes to express his gratitude to Dr. Yokichi Mino, Dr. Shigemi Takayama and Dr. Tadaghi Arai, the Department of Geography, Risshô University, who have given him helpfull suggestions. 